Indonesian Journal of Legality of Law
e-ISSN : 2477-197X
https://postgraduate.universitasbosowa.ac.id/

\title{
KINERJA PENGAWAS PENYIDIK KEPOLISIAN REPUBLIK INDONESIA TERHADAP PEMENUHAN HAK TERSANGKA PADA KEPOLISIAN RESORT PINRANG
}

\section{The Performance of The Republic of Indonesia Police Investigators on The Fulfillment of The Suspects' Rights in Pinrang Police Station}

\author{
Afrizal $^{1}$, Ruslan Renggong ${ }^{2}$, Abd. Haris Hamid ${ }^{2}$ \\ ${ }^{1}$ Kepolisian Resort Pinrang \\ ${ }^{2}$ Program Studi Ilmu Hukum Program Pascasarjana Universitas Bosowa \\ Email: rizalpendolo@gmail.com \\ Diterima: 10 September 2021/Disetujui: 21 Desember 2021
}

\begin{abstract}
ABSTRAK
Tujuan penelitian ini adalah untuk mengetahui dan menganalisis bentuk dan faktor yang memengaruhi pelaksanaan kinerja pengawas penyidik terhadap pemenuhan hak tersangka di Polres Pinrang, dilaksanakan di Kantor Polres Pinrang. Penelitian ini adalah penelitian normatif-empiris dengan pendekatan kualitatif dengan tujuan untuk untuk mengetahui dan menganalisis bentuk dan faktor yang memengaruhi pelaksanaan kinerja pengawas penyidik terhadap pemenuhan hak tersangka di Polres Pinrang, dilaksanakan di Kantor Polres Pinrang. Hasil penelitian menunjukkan bahwa bentuk pelaksanaan kinerja Pengawas Penyidik terhadap pemenuhan hak tersangka di Polres Pinrang telah dilakukan dalam bentuk monitoring, eksaminasi dan supervisi, namun belum berjalan sebagaimana mestinya. Faktor yang memengaruhi pelaksanaan kinerja Pengawas Penyidik terhadap pemenuhan hak tersangka di Polres Pinrang adalah aturan hukum aturan hukum yang ada belum mengakomodir cara pelaksanaan pengawasan, hanya memberikan legalitas kepada Pengawas Penyidik, sarana dan prasarana masih sangat kurang seperti tidak adanya ruangan khusus dan kendaraan operasional bagi Pengawas Penyidik, dan sumber daya manusia hanya 1 (satu) orang Pengawas Penyidik, yakni Kepala Urusan Pembinaan Operesional (Kaur Bin Ops/KBO), yang bertugas juga membantu Kasat Reskrim Polres Pinrang.
\end{abstract}

Kata Kunci: Pengawas Penyidik, Kepolisian, Hak Tersangka.

\begin{abstract}
The purpose of this study was to determine and analyze the forms and factors that influence the conduct of investigators on the rights of suspects at the Pinrang Police, carried out at the Pinrang Police Office. This research is a normative-empirical research with an approach to identify and analyze the forms and factors that influence the performance of supervisors on the fulfillment of the rights of suspects at the Pinrang Police, carried out at the Pinrang Police Office. The results showed that the implementation of the performance of the Investigating Supervisor towards the fulfillment of the suspects' rights at the Pinrang Police had been carried out in the form of monitoring, examination and supervision, but it had not run as it should. Factors that affect the implementation of Investigator Supervision on the rights of investigators at the Pinrang Police are the legal rules that accommodate the implementation of supervision, only provide legality to investigators, facilities and infrastructure that are still very lacking such as the absence of a special room and operational vehicle for the Investigator Supervisor, and human resources that are only 1 (one) Investigating Supervisor, namely the Head of Operations Development Affairs (KBO), who also assists the Pinrang Police Criminal Investigation Unit.
\end{abstract}

Keywords: Investigating Supervisor, Police, Suspect's Rights

This work is licensed under Creative Commons Attribution License 4.0 CC-BY International license

\section{PENDAHULUAN}

Kepolisian merupakan salah satu lembaga penegak hukum, keberadaannya disebutkan di dalam Undang-Undang Dasar Negara Republik Indonesia Tahun 1945 Pasal 30 ayat (4) yang berbunyi bahwa "Kepolisian Negara Republik Indonesia sebagai alat negara yang menjaga keamanan dan ketertiban masyarakat, serta menegakkan hukum.” Kepolisan sebagai penegak hukum juga disebutkan di dalam Undang-
Undang Nomor 2 Tahun 2002 tentang Kepolisian Negara Republik Indonesia (UU Kepolisian), pada Pasal 2 yang menyebutkan bahwa "fungsi kepolisian adalah salah satu fungsi pemerintahan negara di bidang pemeliharaan keamanan dan ketertiban masyarakat, penegakan hukum, perlindungan, pengayoman, dan pelayanan kepada masyarakat."

Sebagai salah satu lembaga penegak hukum dalam sistem peradilan pidana (criminal justice system), polisi 
memiliki wewenang dalam melakukan penyelidikan dan penyidikan. Oleh regulasi yang ada seperti Kitab UndangUndang Hukum Acara Pidana (KUHAP) Pasal 1 angka 2 menyebutkan bahwa "penyidikan adalah serangkaian tindakan penyidik dalam hal dan menurut cara yang diatur dalam undang-undang ini untuk mencari serta mengumpulkan bukti yang dengan bukti itu membuat terang tentang tindak pidana yang terjadi dan guna menemukan tersangkanya."

Mengingat seringnya ada pelanggaran yang dilakukan oleh penyidik terhadap hak-hak tersangka dalam proses penyidikan, maka proses penyidikan yang dilakukan oleh penyidik harus diawasi. Hal tersebut penting dilakukan untuk menjamin kelancaran pelaksanaan penyidikan dan untuk menghindari penyimpangan atau penyalahgunaan penggunaan kewenangan oleh aparat Kepolisia Negara Republik Indonesia, selaku penyidik dan penyelidik dari Markas Besar Kepolisian Negara Republik Indonesia sampai kesatuan wilayah terdepan, harus dilakukan pengawasan dan pengendalian yang efektif ( I Ketut Adi Purnama, 2018).

Hak-hak yang dimiliki oleh tersangka dalam proses penyidikan dapat dilihat pada KUHAP mulai dari Pasal 50 sampai dengan Pasal 68 (Andi Hamzah, 2014). Hak-hak tersebut meliputi:

1. Hak untuk segera diperikasa, diajukan ke pengadilan, dan diadili (Pasal 50 ayat (1), (2), (3)).

2. Hak untuk mengetahui dengan jelas dan bahasa yang dimengerti olehnya tentang apa yang disangkakan dan apa yang didakwakan. (Pasal 51 butir a dan b).

3. Hak untuk memberikan keterangan secara bebas kepada penyidik da hakim seperti tersebut di muka (Pasal 52).

4. Hak untuk mendapatkan juru bahasa (Pasal 53 ayat (1)).

5. Hak untuk mendapatkan bantuan hukum pada setiap tingkat pemeriksaan (Pasal 54).

6. Hak untuk mendapatkan nasihat hukum dari penasihat hukum yang ditunjuk oleh pejabat yang bersangkutan pada semua tingkat pemeriksaan bagi tersangka atau terdakwa yang diancam pidana mati dengan biaya cumacuma.

7. Hak tersangka atau terdakwa yang berkebangsaan asing untuk menghubungi dan berbicara dengan perwakilan negaranya (Pasal 57 ayat (2)).

8. Hak untuk menghubungi dokter bagi tersangka atau terdakwa yang ditahan (Pasal 28).

9. Hak untuk diberitahu kepada keluarganya atau orang lain yang serumah dengan tersangka atau terdakwa yang ditahan untuk mendapatkan bantuan hukum atau jaminan bagi penangguhannya dan hak untuk berhubungan dengan keluarga dengan maksud yang sama di atas (Pasal 59 dan 60).

10. Hak untuk dikunjungi sanak keluarga yang tidak ada hubungannya dengan perkara tersangka atau terdakwa. Untuk kepentingan pekerjaan atau kepentingan kekeluargaan (Pasal 61).

11. Hak tersangka atau terdakwa untuk berhubungan suratmenyurat dengan penasehat hukumnya (Pasal 62)

12. Hak tersangka atau terdakwa untuk menghubungi atau menerima kunjungan rohaniawan (Pasal 63).

13. Hak tersangka atau terdakwa untuk mengajukan saksi dan ahli yang a de charge (Pasal 65).

14. Hak tersangka atau terdakwa untuk menuntut ganti kerugian (Pasal 68).

Selain hak-hak tersangka yang disebutkan di atas, masih ada hak-hak tersangka yang lain, seperti di bidang penahanan, penggeledahan dan lainnya (Andi Hamzah, 2014).
Dalam bidang penahanan, tersangka memiliki sejumlah hak yang bertujuan untuk mencegah terjadinya perlakuan yang tidak manusiawi terhadap tersangka (Ruslan Renggong, 2016) . Adapun hak yang dimiliki oleh para tahanan adalah:

1. Hak untuk tidak disiksa

2. Hak untuk memperoleh pemeriksaan yang cepat.

3. Hak untuk memperoleh bantuan hukum

4. Hak untuk memperoleh pelayanan kesehatan.

5. Hak untuk menerima kunjungan keluarga.

6. Hak atas ganti kerugian dan rehabilitasi.

Semua hak-hak tersangka tersbut di atas merupakan sesuatu yang harus dapat dipastikan pemenuhannya. Hak tersebut tidak boleh diabaikan apalagi dilanggar oleh pihak penyidik yang melakukan proses penyidikan. Pemenuhan hak tersangka merupakan salah satu bentuk ketaatan hukum dan pemenuhan keadilan bagi semua masyarakat, termasuk tersangka. Karena pada dasarnya semua orang memiliki hak yang sama untuk dapat merasakan keadilan dan tidak boleh diperlakukan sewenang-wenang oleh siapa pun, karena itu merupakan sebuah pelanggaran terhadap hukum itu sendiri

Berdasarkan Peraturan Kapolri Nomor 14 tahun 2012 tentang Manajemen Penyidikan Tindak Pidana Pasal 80 disebutkan bahwa: "Pejabat pengemban fungsi pengawasan penyidik meliputi:

a. Tingkat mabes Polri:

1. Kepala Biro Wassidik Ditreskrim;

2. Pengemban fungsi pengawasan pada Baharkam Polri, Korlantas Polri, Biro Wassidik Bareskrim Polri, Densus 88 AT Polri.

b. Tingkat Polda:

1. Kepala Bagian Wassidik Ditreskrim;

2. Pengemban fungsi pengawasan pada Ditlantas; dan

3. Pengemban fungsi pengawasan pada Ditpolair.

c. Tingkat Polres:

1. Kaur Bin Ops (KBO) Satreskrim;

2. KBO Satlantas dan

3. KBO Satpolair

Berdasarkan pasal tersebut di atas, dapat diketahui bahwa pada tingkat Polres yang melakukan pengawasan terhadap penyidik ada 3 yaitu Kaur Bin Ops (KBO) Satreskrim, KBO Satlantas dan KBO Satpolair.

Dalam Peraturan Kapolri Nomor 12 Tahun 2009 tentang Pengawasan dan Pengendalian Penanganan Perkara Pidana di Lingkungan Kepolisian Negara Republik Indonesia, Pasal 36 ayat (2) disebutkan bahwa Perwira Pengawas Penyidik Polri memiliki tugas:

1. Memberikan arahan dan bantuan untuk kelancaran penyidikan.

2. Melakukan pengawasan terhadap tindakan yang dilakukan penyidik,

3. Mencegah terjadinya hambatan penyidikan;

4. Mengatasi hambatan yang menyulitkan penyidikan;

5. Menjamin prinsip tranparansi dan akuntabilitas kinerja penyidik;

6. Meningkatkan kinerja penyidik di bidang penegakan hukum maupun pelayanan polri;

7. Membantu kelancaran komunikasi pihak yang berkepentingan dalam hal ini adalah korban, saksi dan tersangka;

8. Melaporkan perkembangan dan/atau hasil penyidikan kepada pimpinan/pejabat yang berwenang. 


\section{METODE}

Penelitian ini adalah penelitian normatif-empiris dengan pendekatan kualitatif. Penelitian normatif-empiris merupakan penelitian hukum yang dilengkapi dengan data empirik atau dapat disimpulkan bahwa penelitian normatif-empiris adalah jenis penelitian hukum normatif yang didukung dan dilengkapi dengan data empirik (Irwansyah, 2020). Dalam penelitian ini ada (2) jenis data yang digunakan yaitu: data primer dan data sekunder. Data primer, adalah data yang diperoleh secara langsung dari sumbernya, baik melalui wawancara, observasi maupun laporan dalam bentuk dokumen tidak resmi yang kemudian diolah oleh peneliti. Sedangkan data sekunder, yaitu data yang diperoleh dari dokumen-dokumen resmi, buku-buku yang berhubungan dengan objek penelitian, hasil penelitian dalam bentuk laporan, skripsi, tesis, disertasi, dan peraturan perundangundangan (Zainuddin Ali, 2014).

Penelitian ini menggunakan teknik pengumpulan data dengan cara melakukan wawancara (interview) yang dilakukan dengan mengajukan pertanyaan kepada informan dengan tujuan untuk menggali secara mendalam hal-hal yang penting yang mungkin belum terjangkau dari data yang didapatkan dari lokasi penelitian. Pengamatan (Observasi) yang dilakukakan dengan terjun langsung ke lokasi penelitian mengamati objek penelitian, dan dengan cara dengan dokumentasi melalui penelusuran dokumen tertulis yang terkait dengan permasalahan penelitian dengan menelusuri berbagai buku-buku dan karya ilmiah lainnya yang relevan dengan penelitian ini.

\section{HASIL DAN PEMBAHASAN}

\subsection{Bentuk Pelaksanaan Kinerja Pengawas Penyidik Terhadap Pemenuhan Hak Tersangka di Polres Pinrang}

Untuk memastikan pemenuhan hak tersangka dalam proses penyidikan yang dilakukan oleh penyidik Polri di Polres Pinrang, maka penyidik Polri yang melakukan proses penyidikan terhadap tersangka harus diawasi oleh Pengawas Penyidik (Wassidik). Dalam melakukan pengawasan terhadap penyidik, Pengawas Penyidik di Polres Pinrang melakukannya dengan beberapa bentuk sebagai berikut.

\section{a. Monitoring}

Salah satu bentuk pengawasan yang dilakukan oleh pengawas penyidik polri terhadap penyidik adalah dengan melakukan monitoring. Monitoring dilakukan untuk memastikan proses penyidikan berjalan sesuai dengan aturan yang ada, serta tidak adanya pelanggaran terhadap hak-hak tersangka yang sedang menjalani prose penyidikan. Mengenai monitoring yang dilakukan oleh Pengawas Penyidik di Polres Pinrang, IPTU Sukri selaku Pengawas Penyidik Polri Polres Pinrang (wawancara, 1 Juli 2021) menyebutkan bahwa: "sebagai pengawas penyidik, kami melakukan pengawasan atau monitoring terhadap proses penyidikan yang dilakukan oleh penyidik untuk memastikan bahwa tidak ada pelanggaran yang dilakukan mulai dari awal hingga akhir, saat gelar perkara, termasuk harus tertib administrasi. Semuanya kami monitoring. Hal itu untuk memastikan juga pemenuhan hakhak tersangka."

Berdasarkan hasil wawancara tersebut di atas, dapat diketahui bahwa pengawasan yang dilakukan oleh pengawas penyidik dengan melakukan monitoring terhadap proses penyidikan yang dilakukan oleh agar penyidikan dapat berjalan dengan baik sesuai dengan peraturan hukum yang ada. Hal tersebut memang perlu dilakukan demi memastikan tidak adanya pelanggaran dalam proses penyidikan dan terpenuhinya hak-hak tersangka. Dengan adanya pengawasan yang dilakukan, maka hal tersebut dapat menghindarkan penyidik dari perbuatan yang menyimpang seperti penyalahgunaan wewenang sehingga proses hukum dapat berjalan dengan baik. Selain itu, tersangka juga dapat mendapatkan keadilan dalam proses hukum yang dilakukan. Sehingga akan membuat tersangka merasa puas dengan proses hukum yang dilakukan karena sudah sesuai dengan aturan hukum yang berlaku.

Mengenai monitoring yang dilakukan oleh Pengawas Penyidik Polri, diakuai oleh Bripka Muhammad Hasrul selaku penyidik pada Polres Pinrang (wawancara, 2 Juli 2021) bahwa: "ketika kami melakukan penyidikan terhadap tersangka, Pengawas Penyidik selalu hadir memantau kami dalam proses penyidikan. Hal tersebut, tentu membuat kami tidak berani melakukan penyimpangan hukum terhadap hakhak tersangka. Jadi hak-hak tersangka akan terpenuhi dari awal penyidikan bahkan hingga berkas perkara kami limpahkan ke kejaksaan. Semua diawasi dengan baik oleh Wassidik." Hal senada juga diungkapkan oleh Briptu Muhammad Nurwijaya (wawancara, 2 Juli 2021) bahwa: "bukan hanya pada saat penyidikan, Wassidik pun memantau kami juga pada saat gelar perkara. Dan memang sebenarnya kami berharap agar Wassidik dapat hadir dalam semua tahapan penyidikan yang kami lakukan. Agar tidak ada kecurigaan bahwa kami melakukan pelanggaran saat proses penyidikan yang kami lakukan. Meskipun memang Wasidik tidak hadir karena ada kesibukan lain."

Berdasarkan pengakuan kedua penyidik tersebut di atas, dapat diketahui bahwa Pengawas Penyidik Polri yang ada di Polres Pinrang memang telah menjalankan tugasnya dalam melakukan pengawasan kepada penyidik yang melakukan proses penyidikan terhadap tersangka. Meski tidak selalu hadir karena adanya kesibukan dan tugas lain. Dengan adanya pengawasan tersebut membuat penyidik tidak berani melakukan pelanggaran. Pengawasan yang dilakukan pun sudah sangat memadai karena mulai dari awal penyidikan hingga selesainya penyidikan. Dengan demikian dapat dipastikan bahwa penyidikan yang dilakukan akan sesuai dengan aturan yang berlaku.

Sementara salah satu tersangka Andi Kadir kasus penganiayaan mengungkapkan, (wawancara, 2 Juli 2021) bahwa: "saat saya diperiksa oleh polisi (penyidik), ya ada pengawas yang hadir di tempat saya diperiksa itu. Saya tahu karena disampaikan oleh polisi bahwa bahwa pemeriksaan itu diawasi, jadi polisi melarang saya takut karena mereka tidak akan berani melakukan hal yang macam-macam karena ada pengawasnya yang hadir." Selain itu, tersangka lain atas nama Muhammad Agung Santoso yang merupakan tersangka kasus Narkoba mengungkapkan (wawancara, 2 Juli 2021) bahwa: 
"pengawas hadir dalam pemeriksaan saya, dia ikut menyaksikan proses yang dilakukan oleh penyidik bersama dengan penasehat hukum saya. Sehingga polisi yang memeriksa saya (penyidik) serius dalam menjalankan tugasnya. Dan itu sangat baik menurut saya."

Berdasarkan hasil wawancara dengan kedua tersangka tersebut di atas dapat dipahami bahwa pengawas penyidik Polri hadir dalam proses penyidikan yang dilakukan oleh Penyidik Polri. Berdasarkan hasil wawancara dengan semua informan di atas, maka dapat dipastikan bahwa pelaksanaan kinerja pengawas penyidik terhadap pemenuhan hak tersangka di Polres Pinrang yang dilakukan dalam bentuk monitoring telah dilaksanakan. Meski tidak semua proses penyidikan dapat diawasi oleh pengawas penyidik. Pemantauan atau monitoring memang perlu dilakukan agar hak-hak tersangka tersebut dapat terpenuhi dengan baik pula. Selain melakukan monitoring di ruangan, pengawas juga melakukan pengamatan tindakan penyidikan di lapangan dengan tujuan untuk menetahui mengenai penerapan teknik penangkapan, penggeledahan, penyitaan, penahanan, pemeriksaan; Proporsionalitas kewajaran tindakan yang diterapkan (agar tidak berlebihan atau sebaliknya agar tidak ragu-ragu) dan teknik membawa, mengawal, memperlakukan tersangka, termasuk terhadap korban dan para saksi.

Mengenai alasan tidak semua proses penyidikan dimonitong oleh Pengawas Penyidik, IPTU Sukri selaku Pengawas Penyidik Polri pada Polres Pinrang mengungkapkan (wawancara, 2 Agustus 2012) bahwa: "karena banyak kasus yang diproses di Polres Pinrang ini maka, tentu tidak semua dapat kami pantau atau monitoring. Apalagi kami hanya seorang diri sebagai Wassidik. Jadi hanya kasus-kasus tertentu yang kami pantau. Seperti kasus atau perkara sulit dan sangat sulit dan yang mendapatkan perhatian khusus. Tapi kalau kami ada waktu, pasti semua kami pantau dari awal hingga akhir." Dari penjelasan tersebut di atas dapat diketahui bahwa ternyata alasan tidak semua proses penyidikan yang dilakukan oleh penyidik dapat dipantau atau dimonitoring oleh pengawas penyidik adalah karena banyaknya kasus yang terjadi, serta adanya kesibukan lain yang dilakukan oleh pengawas penyidik. Hanya perkara yang sulit dan sangat sulit serta yang mendapatkan monitoring. Jadi perkara yang temasuk dalam kriteria perkara mudah dan sedang tidak terlalu mendapatkan pemantauan atau monitoring. Apalagi pengawas penyidik hanya seorang diri sehingga tidak dapat memonitoring semua kasus yang ditangani oleh penyidik.

Dengan tidak semua proses penyidikan dapat diberikan dipantau atau dimonitoring oleh pengawas penyidik, maka dapat dikatakan bahwa monitong belum berjalan dengan baik. Walaupun memang telah banyak yang dipantau dengan baik, tapi secara keseluruhan belum terlaksana sebagaimana yang seharusnya. Sehingga monitoring yang dilakukan oleh pengawas penyidik belum optimal, karena ternyata tidak semua proses penyidikan yang dilakukan di Polres Pinrang dapat dimonitong atau dipantau dari awal hingga akhir dari pengawas penyidik. Harusnya demi untuk memastikan proses penyidikan yang dilakukan oleh penyidik telah berjalan dengan baik dan benar, maka semua harus dilakukan monitoring atau pemantaun dari awal hingga akhir. Hal ini penting demi memastikan kerja penyidik dalam proses penyidikan telah sesuai dengan aturan hukum yang berlaku serta tidak adanya pelanggaran terhadap hak-hak tersangka.

\section{b. Eksaminasi}

Mengenai eksaminasi yang dilakukan oleh pengawas penyidik disebutkan oleh IPTU Sukri selaku Pengawas Penyidik Polri di instansi Polres Pinrang yang menyebutkan (wawancara, 1 Juli 20210 bahwa: "kami melakukan eksaminasi dengan melakukan penelitian dan penilaian keabsahan dan ketelitian administrasi penyidikan yang dilakukan oleh penyidik. Hal itu kami lakukan untuk memastikan tidak ada pelanggaran yang dilakukan oleh penyidik." Sementara Briptu Muhammad Nurwijaya selaku penyidik pada Polres Pinrang mengukapkan (wawancara, 2 Juli 2021) bahwa: "dengan adanya eksaminasi yang dilakukan oleh Wassidik, maka kami merasa sangat terbantu karena kekurang yang telah kami lakukan saat melakukan penyidikan terhadap tersangka dapat kami ketahui dengan demikian maka tidak akan kami uangi lagi kesalahan tersebut."

Berdasarkan hasil wawancara di atas bahwa memang pada sadarnya eksaminasi atau penelitian yang dilakukan terhadap hasil penyidikan memang perlu dilakukan untuk mengetahui apakah proses penyidikan telah berjalan dengan baik. Hal tersebut dilakukan demi perbaikan sehingga kesalahan dalam proses penyidikan tidak terulang lagi pada proses penyidikan selanjutnya. Ada beberapa yang dilakukan penelitian/eksaminasi dari segi administrasi penyidikan. Seperti yang disampaikan oleh oleh IPTU Sukri selaku Pengawas Penyidik Polri Polres Pinrang (wawancara, 1 Juli 2021) bahwa: "dari segi administrasi kami meneliti surat panggilan, penangkapan, penggeledahan, penyitaan, penahanan, dan sebagainya. Yang menjadi sasaran penelitian administrasi penyidikan antara lain: dasar hukum yang digunakan dalam penerbitan suatu surat, laporan atau kegiatan administrasi lainnya. Untuk menentukan identitas seseorang atau badan hukum yang menjadi objek perkara; penulisan kata, nama, alamat, tanggal, nomor surat, dan ketentuan perundang-undangan atau peraturan yang menjadi dasar penyususnan dan kelengkapan berkas. Penelitian bukti permulaan untuk dasar penangkapan, penggeledahan, penyitaan dan tindakan kepolisian lainnya sesuai dengan perundang-undangan dan peraturan yang berlaku. Penelitian bukti yang cukup (asas legalitas) dan aspek kepatutan untuk penerapan penahanan."

Berdasrkan hasil wawancara di atas, dapat diketahui bahwa Pengawas Penyidik Polri di Polres Pinrang telah melakukan eksaminasi dari segi administrasi dengan melakukan penelitian terhadap surat panggilan, penangkapan, penggeledahan, penyitaan, penahanan, dan sebagainya. Selain itu, pengawasan juga ditujukan pada sasaran penelitian administrasi penyidikan yang meliputi: dasar hukum yang digunakan dalam penerbitan suatu surat, laporan atau kegiatan administrasi lainnya. Untuk menentukan identitas seseorang atau badan hukum yang menjadi objek perkara; penulisan kata, nama, alamat, tanggal, nomor surat, dan ketentuan perundang-undangan atau peraturan yang menjadi dasar penyususnan dan kelengkapan berkas. Penelitian bukti permulaan untuk dasar penangkapan, penggeledahan, penyitaan dan tindakan kepolisian lainnya sesuai dengan perundang-undangan dan peraturan yang berlaku.

Selain itu, juga meneliti terkait dengan bukti yang cukup (asas legalitas) dan aspek kepatutan untuk penerapan penahanan. Hal tersebut penting dilakukan sebagai uapaya agar hak-hak tersangka dapat dipastikan terpenuhi dengan baik, sehingga tidak ada pelanggaran di dalamnya yang pada 
akhirnya melahirkan keadilan bagi semua orang sebagaimana tujuan hukum, yakni keadilan, kemanfaatan dan kepastian hukum. Meski ketiga tujuan hukum tersebut tidak dapat dicapai secara bersamaan, namun yang terpenting adalah adanya keadilan yang dapat dirasakan oleh semua pihak sebagai wujud dari negara hukum yang dianut di Indonesia ini. Mengenai apakah semua proses penyidikan yang dilakukan oleh penyidik mendapatkan eksaminasi dari pengawas penyidik, IPTU Sukri selaku Pengawas Penyidik Polri Polres Pinrang yang menyebutkan (wawancara, 2 Agustus 2021) bahwa: "tidak semua proses penyidikan yang telah dilakukan oleh penyidik kami eksaminasi. Karena kami beranggapan bahwa kalau perkara mudah dan sedang, pasti penyidik telah faham mengerti sehingga proses penyidikan yang dilakukan tidak ada masalah. Kecuali perkara yang berat dan sangat berat dan mendapatkan perhatian secara luas itu yang kami eksaminasi untuk memastikan apakah telah sesuai atau tidak. Apalagi kami hanya seorang diri sebagai pengawas penyidik banyak juga yang harus kami kerjakan. Tapi kasus yang kami eksaminasi, kami pasti berusaha dengan semaksimal mungkin."

Berdasarkan hasil wawancara tersebut di atas, dapat diketahui bahwa ternyata tidak semua proses penyidikan yang telah dilakukan oleh penyidik di Polres Pinrang mendapatkan eksaminasi dari Pengawas Penyidik. Hanya kasus yang termasuk kriteria sulit dan sangat sulit serta yang mendapatkan perhatian yang luas dari masyarakat yang mendapatkan eksaminasi. Jadi perkara yang termasuk dalam kriteria mudah dan sedang tidak menjadi prioritas untuk dilakukan eksaminasi oleh pengawas penyidik. Dengan demikian dapat dikatakan bahwa eksaminasi yang harusnya dilakukan oleh pengawas penyidik belum maksimal karena tidak semua mendapatkan eksaminasi/penelitian. Padahal eksaminasi ini penting demi menjamin bahwa proses penyidikan yang telah dilakukan oleh penyidik telah berjalan dengan baik tampa adanya kesalahan baik dalam bentuk administrasi, dasar hukum maupun dalam bentuk tindakan yang dilakukan oleh penyidik.

\section{c. Supervisi}

Mengenai supervisi yang dilakukan oleh pengawas penyidik, disebutkan oleh IPTU Sukri selaku Pengawas Penyidik Polri di Polres Pinrang yang menyebutkan (wawancara, 1Juli 2012) bahwa: "kami melakukan supervisi dengan memberikan bimbingan dan koreksi langsung kepada penyidik agar dalam proses penyidikan yang mereka lakukan tidak ada kesalahan." Dari hasil wawancara di atas dapat diketahui bahwa Pengawas Penyidik Polri di Polres Pinrang melakakukan supervisi berupa memberikan bimbingan maupun koreksi atas proses penyidikan yang dilakukan oleh penyidik. Hal tersebut memang perlu dilakukan agar keslahan dan kekurang yang dilakukan oleh penyidik dapat dihindari, termasuk dalam pelanggaran yang berkaitan dengan pemenuhan hak-hak tersangka.

Sementara menurut Bripka Muhammad Hasrul selaku Penyidik Polri di Polres Pinrang mengungkapkan mengenai supervisi yang dilakukan oleh Pengawas Penyidik(wawancar, 2 Juli 2021) bahwa: "dengan adanya supervisi yang dilakukan oleh Wassidik, maka tentu sangat membantu bagi kami dalam proses penyidikan yang kami lakukan. Karena dapat memberikan kami pemahaman sehingga kesalahan dalam proses penyidikan akan dapat dihindari." Berdasarkan pengakuan Penyidik atas supervisi yang dilakukan oleh pengawas penyidik, bahwa supervisi tersebut sangat membantu penyidik karena dengan adanya supervisi yang dilakukan, maka penyidik mendapatkan pemahaman mendalam tentang proses penyidikan. Hal tersebut perlu dilakukan agar dalam proses penyidikan yang dilakukan tidak terdapat kesalahan, dan yang paling penting adalah terpenuhinya hak-hak tersangka.

Selain itu, Pengawas Penyidik melakukan supervisi juga pada hasil penindakan/penyidikan. Seperti yang disampaikan oleh IPTU Sukri (wawancara, 1 Juli 2021) bahwa: "apabila diperlukan maka kami juga melakukan supervisi terkait dengan teknik penangan barang bukti yang meliputi pengambilan, pengamanan, pembungkusan, penyegelan, pengangkutan, penyimpanan, pemeriksaan ke Labfor, penyisihan, pelelangan dan tindakan lain sesuai dengan aturan yang berlaku dalam penangan barang bukti; Hasil pemeriksaan dan pemberkasan dengan sasaran pertama penerapan pasal, kelengkapan alat bukti; dan bahkan kondisi tahanan."

Dari penjelasan tersebut di atas dapat diketahui bahwa Pengawas Penyidik di Polres Pinrang IPTU Sukri telah melakukan supervisi dengan berbagai objek, seperti teknik penangan barang bukti yang meliputi pengambilan, pengamanan, pembungkusan, penyegelan, pengangkutan, penyimpanan, pemeriksaan ke Laboratorium forensik (Labfor), penyisihan, pelelangan dan tindakan lain sesuai dengan aturan yang berlaku dalam penangan barang bukti; hasil pemeriksaan dan pemberkasan dengan sasaran pertama penerapan pasal, kelengkapan alat bukti; dan bahkan kondisi tahanan. Dan itu dilakukan sebagai uapaya untuk memenuhi hak-hak tersangka dalam proses penyidikan. Sehingga tersangka dapat merasakan keadilan dalam proses penyidikan yang dijalaninya.

Mengenai apakah semua poses penyidikan mendapatkan supervisi dari Pengawas Penyidik, IPTU Sukri selaku Pengawas Penyidik Polri pada Polres Pinrang mengungkapkan (wawancara, 2 Agustus 2021) bahwa: "karena banyak kasus yang diproses di Polres Pinrang ini maka, tentu tidak semua dapat kami supervisi. Apalagi kami hanya seorang diri sebagai Wassidik. Jadi ada perkara tertentu yang mendapatkan supervisi. Seperti perkara yang sulit dan sangat sulit serta yang mendapatkan perhatian khusus."

Dari penjelasan tersebut di atas dapat diketahui bahwa ternyata tdak semua proses penyidikan yang dilakukan oleh penyidik dapat diberikan supervisi oleh pengawas penyidik. Hal tersebut terjadi karena banyaknya kasus yang terjadi serta adanya kesibukan lain yang dilakukan oleh pengawas penyidik. Apalagi penyidik hanya seorang diri sehingga tidak dapat memberikan supervisi pada semua perkara yang ditangani oleh penyidik. Hanya perkara yang sulit dan yang sangat sulit yang mendapatkan prioritas. Perkara yang mudah dan sedang tidak menjadi prioritas untuk mendapatkan supervisi. Dengan tidak semua proses penyidikan dapat diberikan supervisi oleh pengawas penyidik, maka dapat dikatakan bahwa supervisi belum berjalan dengan baik. Walaupun memang telah ada yang dilakukan dan berjalan 
dengan baik, tapi secara keseluruhan belum terlaksana sebagaimana yang diharuskan oleh regulasi yang ada. Sehingga supervisi yang dilakukan oleh pengawas penyidik belum optimal, karena ternyata tidak semua proses penyidikan yang dilakukan di Polres Pinrang mendapatkan supervisi dari pengawas penyidik.

Harusnya demi memastikan proses penyidikan yang dilakukan oleh penyidik telah berjalan dengan baik, maka semua harus diberikan supervisi. Dengan demikian kepercayaan terhadap lembaga kepolisian dapat terwujud, mengingat selama ini tidak jarang ada pandangan miring dari masyarakat kepada lembaga kepolisian yang kerap dianggap melakukan berbagai pelanggaran saat melakukan proses penyidikan terhadap tersangka, meskipun hal tersebut dilakukan oleh oknun yang tidak bertanggungjawab. Namun berdampak kepada kepercayaan masyarakat terhadap instansi kepolisian. Sehingga jelas akan berdampak kepada kepercayaan masyarakat ke lembaga kepolisian sehinga merugikan lembaga kepolisian.

\subsection{Faktor yang Memengaruhi Pelaksanaan Kinerja Pengawas Penyidik Terhadap Pemenuhan Hak Tersangka di Polres Pinrang}

\section{a. Aturan Hukum}

Salah satu faktor yang dapat memengaruhi pelaksanaan kinerja pengawas penyidik dalam menjalankan tugasnya mengawasi proses penyidikan terhadap tersangka yang dilakukan oleh penyidik adalah aturan hukum. Karena aturan hukum tersebut merupakan pedoman bagi penegak hukum dalam menjalankan tugasnya. Penegakan hukum dapat berjalan dengan baik salah satu faktor penentunya adalah adanya aturan hukum yang melandasinya. Tampa aturan hukum yang baik, maka penegakan hukum tidak akan memberikan rasa keadilan bagi semua orang.

Mengenai pengaruh aturan hukum dalam pelaksanaan kinerja pengawas penyidik terhadap pemenuhan hak tersangka di Polres Pinrang, penulis melakukan wawancara dengan Pengawas Penyidik (Wassidik) di Polres Pinrang, IPTU Sukri. Dalam wawancara tersebut IPTU Sukri mengemukakan (wawancara, 1 Juli 2021) bahwa: "ada beberapa aturan hukum yang menjadi landasan kami dalam melakukan pengawasan. Aturan hukum itu sangat penting sebagai landasan hukum bagi kami agar apa yang kami lakukan sah. Sehingga dari segi legalitas, kami cukup terbantu karena dengan adanya aturan hukum itu, kami dapat menjalankan tugas."

Berdasarkan hasil wawancara di atas, dapat diketahui bahwa aturan hukum menjadi salah satu faktor yang memengaruhi pelaksanaan kinerja pengawas penyidik dalam menjalankan tugasnya melakukan pengawasan terhadap Penyidik. Dengan adanya aturan hukum tersebut, maka membuat Pengawas Penyidik dapat sah dalam menjalankan tugas karena aturan hukum tersebut memberikan legalitas pengawasan. Sebagaimana telah diketahui bahwa ada beberapa aturan yang menjadi dasar hukum bagi pelaksanaan pengawasan yang dilakukan oleh Pengawas Penyidik. Aturan hukum tersebut seperti Peraturan Kapolri Nomor 14 tahun 2012 tentang Manajemen Penyidikan Tindak Pidana yang merupakan pengganti dari Peraturan Kapolri Nomor 12 Tahun 2009 tentang Pengawasan dan Pengendalian Penanganan Perkara Pidana di Lingkungan Kepolisian Negara Republik Indonesia.

Dalam Peraturan Kapolri Nomor 14 tahun 2012 tentang Manajemen Penyidikan Tindak Pidana tentang Manajemen
Penyidikan Tindak Pidana Pasal 80 disebutkan bahwa: pejabat pengemban fungsi pengawasan penyidik meliputi:

a. Tingkat mabes Polri:

1. Kepala Biro Wassidik Ditreskrim;

2. Pengemban fungsi pengawasan pada Baharkam Polri, Korlantas Polri, Biro Wassidik Bareskrim Polri, Densus 88 AT Polri.

b. Tingkat Polda:

1. Kepala Bagian Wassidik Ditreskrim;

2. Pengemban fungsi pengawasan pada Ditlantas; dan

3. Pengemban fungsi pengawasan pada Ditpolair.

c. Tingkat Polres:

4. Kaur Bin Ops (KBO) Satreskrim;

5. KBO Satlantas dan

6. KBO Satpolair

Dari pasal tersebut di atas, dapat diketahui bahwa pada tingkat Polres yang melakukan pengawasan terhadap penyidik ada 3 yaitu Kaur Bin Ops (KBO) Satreskrim, KBO Satlantas dan KBO Satpolair. Namun di Polres Pinrang hanya 1 pengawas penyidik yakni IPTU Sukri yang merupakan Kaur Bin Ops (KBO) Satreskrim Polres Pinrang.

Meski aturan hukum telah memberikan legalitas akan pengawasan yang dilakukan oleh pengawas penyidik, namun pada dasarnya aturan hukum yang ada tidak ada yang memberikan petunjuk secara detail mengenai pengawasan. Seperti yang disampaikan oleh IPTU Sukri yang merupakan Wassidik sekaligus Kaur Bin Ops (KBO) Satreskrim Polres Pinrang yang menyebutkan (wawancara, 1 Juli 2021) bahwa: "aturan hukum mengatur tentang pengawasan yang dilakukan oleh kami sebagai Wassidik ada. Namun, belum mengatur secara detail terkait dengan prosedur pelaksanaan pengawasan. Sehingga ini menjadi problem bagi kami dalam melakukan pengawasan. Aturan hanya menentukan siapa yang melakukan pengawasan terhadap penyidik, tapi caranya belum dijelaskan secara detail hanya secara garis besarnya saja."

Berdasarkan hasil wawancara di atas, dapat dipahami bahwa sampai saat ini aturan hukum yang khusus mengatur tentang cara pengawasan yang dilakukan oleh pengawas penyidik belum mengatur cara pengawasan secara detail. Hal ini dapat menjadi faktor penghambat bagi pengawas penyidik. Belum lagi tidak adanya sanksi yang dapat diberikan kepada pihak Polres yang tidak memenuhi aturan hukum terkait pemenuhan pengawas penyidik. Seperti misalnya harus ada minimal 3 (tiga) yang melakukan pengawasan, tapi kenyataannya di Polres Pinrang hanya 1 (satu) orang melakukan pengawasan terhadap penyidik. Hanya IPTU Sukri yang merupakan Wassidik sekaligus Kaur Bin Ops (KBO) Satreskrim Polres Pinrang. Padahal menurut aturan KBO Satlantas dan KBO Satpolair juga harusnya melaksanakan pengawasan terhadap penyidik Polri di Polres Pinrang.

\section{b. Sarana dan Prasarana}

Sarana dan prasarana merupakan sesuatu yang sangat penting untuk menunjang kinerja sebuah lembaga atau institusi atau bahkan seseorang dalam melaksanakan tugas yang diberikan. Sarana dan prasarana tersebut merupakan salah satu faktor penentu keberhasilan dalam menjalankan tugas yang diberikan sehingga kinerja yang dihasilkan sesuai dengan yang diharapkan. Dengan demikian apabila sarana dan prasaran penunjang memadai, maka kinerja yang dihasilakan akan maksimal. Begitu pula sebaliknya, apabila sarana dan prasaran ini kurang, maka kinerja yang dihasilakan pun tidak akan memadai. 
Dengan demikian maka dapat dipastikan bahwa keberadaan sarana dan prasarana akan memengaruhi kinerja yang dihasilakan oleh sebuah instansi, lembaga atau pun seseorang dalam menjalankan tugasnya. Kurangnya sarana dan prasarana dapat menjadi faktor yang menghambat pelaksanaan tugas sebuah lembaga, termasuk pelaksanaan kinerja Pengawas Penyidik terhadap pemenuhan hak tersangka di Polres Pinrang. Untuk mengetahui sejauh mana pengaruh sarana dan prasarana sebagai salah satu faktor yang memengaruhi pelaksanaan kinerja Pengawas Penyidik terhadap pemenuhan hak tersangka di Polres Pinrang, penulis melakukan wawancara dengan pihak Pengawas Penyidik (Wassidik) di Polres Pinrang, IPTU Sukri yang menyebutkan (wawancara, 1 Juli 2021) bahwa: "sarana dan prasarana yang ada masih minim dalam mendukung tugas kami dalam melakukan pengawasan terhadap penyidik. Meski demikian kami tetap berusaha melakukan pengawasan dengan baik agar tersangka tetap mendapatkan hak-haknya pada saat proses penyidikan berlangsung."

Berdasarkan hasil wawancara di atas dapat diketahui bahwa kurangnya sarana dan prasaran yang ada di Polres Pinrang merupakan salah satu faktor yang memengaruhi pelaksanaan kinerja Pengawas Penyidik terhadap pemenuhan hak tersangka di Polres Pinrang. Kurangnya sarana dan prasarana tersebut menjadikan pengawasan yang dilakukan menjadi tidak efektif, meski dalam pengakuannya, IPTU Sukri mengakatakan bahwa sebagai pengawas ia tetap berusaha melakukan pengawasan dengan baik meski tidak didukung oleh adanya sarana dan parasana yang memadai. Seperti yang diungkapakan oleh Pengawas Penyidik (Wassidik) di Polres Pinrang, IPTU Sukri yang menyebutkan (wawancara, 1 Juli 2021) bahwa: "kami tidak punya rungan khusus sehingga dapat menghambat kinerja kami. Selain itu, kami juga tidak punya kendaraan opersional sehingga kesulitan menjangkau Polsek yang ada. Apalagi di wilayah hukum Polres Pinrang ini, ada 10 Polsek, dan mereka tidak punya Wassidik, jadi kami sendiri yang juga harus melakukan pengawasan ke sana."

Berdasarkan hasil wawancara tersebut di atas dapat dipahami bahwa sarana dan prasarana pendukung kinerja bagi Pengawas Penyidik sangat tidak memadai. Sehingga dengan demikian maka Pengawas Penydidik akan sangat kesulitan menjangkau Polsek yang ada di wilayah hukum Polres Pinrang yang ada di wilayah kecamatan yang jaraknya jauh dari Polres. Dengan demikian meski Pengawas Penyidik telah berusaha dengan sekuat tenaga untuk melakukan pengawasan maka sulit akan terwujud, utamanya penyidikan yang dilakukan di Polsek. Mengingat jarak Polsek dengan kantor Polres terbilang jauh.

Namun, dalam pandangan penulis meski telah berusaha melakukan pengawasan dengan baik, tampa adanya dukungan sarana dan prasaran yang memadai, maka pengawasan yang dilakukan tidak akan berhasil dengan baik seperi kalau adanya sarana dan prasarana yang memadai. Karena sarana dan prasarana yang memadai merupakan salah satu faktor penentu kebehasilan sebuah pekerjan sehingga melahirkan sebuah kinerja yang memuaskan, apalagi kalau didukung oleh kesungguhan dan integritas yang tinggi dari Pengawas Penyidik dalam menjalankan tugasnya untuk memastikan proses penyidikan yang dilakukan oleh Penyidik tidak menghilangkan hak-hak tersangka. Jadi kesungguhan dan integritas Pengawas Penyidik dalam menjalankan tugasnya dan didukung dengan sarana dan prasarana yang memadai, maka akan dipastikan pengawasan yang dilakukan oleh Pengawas Penyidik di Polres Pinrang akan berjalan dengan baik. Tapi tampa adanya sarana dan prasarana pendukung yang memadai, maka pelaksanaan kinerja tersebut akan salit terwujud bahkan mustahil dapat menghasilkan kinerja yang baik sesuai dengan keinginan dan harapan masyarakat.

Dengan demikian maka pemenuhan hak-hak tersangka yang menjalani proses penyidikan akan sulit terwujud. Sehingga aparat kepolisian yang merupakan salah satu penegak hukum, justru perpotensi untuk melanggar hukum yang ada dengan melakukan kesewenang-wenangan karena tidak memenuhi hak-hak tersangka. Hal tersebut dapat menjadi pemicu timbulnya ketidakpercayaan masyarakat akan lembaga kepolisian.

\section{c. Sumber Daya Manusia}

Keberadaan Sumber daya manusia (SDM) atau orangorang ada di dalam sebuah institusi atau lembaga merupakan salah satu faktor penting, mengingat orang tersebut yang akan melakukan pekerjaan sehingga fungsi maupun tugas dan tanggungjawab yang ada pada instusi tersebut dapat dilaksanakan dengan baik. Dengan demikain keberdaan sumber daya manusia (SDM) merupakan salah satu faktor penting untuk mendukung keberhasilan suatu organisasi atau lembaga. Dengan sumber daya manusia yang memadai dan kemampuan yang mumpuni serta memiliki integritas yang baik, akan melahirkan sebuah kinerja yang baik. Dengan demikian keberhasilan dalam menjalankan tanggungjawab akan dapat dipastikan menjadi sesautu yang mudah diraih. Tetapi apabila sumber daya manusia yang tidak memadai, tidka memiliki kempotensi serta tidak berintegritas, maka tujuan yang telah dicanangkan akan mustahil terwujud sesaui dengan harapan.

Olehnya itu, sumber daya manusia yang memadai dan kemampuan yang mumpuni serta memiliki integiritas yang baik menjadi sesuatu yang mutlak diperlukan di dalam sebuah instansi atau lembaga. Termasuk lembaga seperti Kepolisian, seperti Polres Pinrang yang melakukan penegakan hukum pada proses penyidikan yang berkeadilan, maka dibutuhkan Pengawas Penyidik dengan jumlah yang memadai, memiliki kemampuan yang mumpuni serta integiritas yang baik sehingga dapat menjalankan tugas dan tanggungjawabnya mengawasi setiap proses penyidikan terhadap tersangka yang dilakukan oleh penyidik.

Mengenai sumber daya manusia, Pengwas Penyidik Polri yang ada di Polres Pinrang, penulis melakukan wawancara dengan Pengawas Penyidik (Wassidik) di Polres Pinrang, IPTU Sukri yang menyebutkan (wawancara, 1 Juli 2021) bahwa: "dari segi jumlah, pengawas penyidik yang ada di Polres Pinrang ini masih sangat kurang, hanya kami seorang. Sehingga kami tidak bisa mengawasi semua penyidik yang melakukan proses penyidikan utamanya di Polsek. Kalau yang ada di sini (Polres Pinrang) bisa saja kami awasi tapi di Polsek pasti kami kesulitan." Berdasrkan hasil wawancara tersebut di atas, maka dapat diketahui bahwa ternyata jumlah pengawas penyidik yang ada di Polres Pinrang masih sangat kurang 
yakni hanya 1 (satu) orang sehingga memengaruhi pelaksanaan kinerja Pengawas Penyidik terhadap pemenuhan hak tersangka di Polres Pinrang. Selain itu, Pengawas Penyidik (Wassidik) di Polres Pinrang, IPTU Sukri juga mengemukakan (wawancara, 1 Juli 2021) bahwa: "Karena cuma kami seorang diri, pasti tidak efektif pengawasan yang kami lakukan disebabkan kami juga punya tugas lain sebagai kepala urusan pembinaan operesional (Kaur Bin Ops/KBO) yang bertugas sebagai pembantu Kasat Reskrim di luar tugas kami sebagai Wassidik."

Berdasarkan hasil wawancara di atas pula, dapat diketahui bahwa Pengawas Penyidik (Wassidik) di Polres Pinrang, IPTU Sukri juga memiliki tugas lain sebagai Kepala Urusan Pembinaan Operesional (Kaur Bin Ops/KBO) yang bertugas membantu Kasat Reskrim Polres Pinrang. Dengan adanya tugas lain tersebut, maka tentu akan mempengaruhi kinerja Pengawas Penyidik tersebut untuk bisa maksimal dalam menjalankan tugas sebagai Wassidik. Apalagi Tugas sebagai Wassidik bisa dikatakan cukup berat untuk memastikan proses penyidikan dapat berjalan sesuai dengan aturan hukum yang ada.

Untuk mengetahui mengetahui tugas pokok Pengawas Penyidik Polri pada Polres Pinrang dapat dilihat pada tabel 1 berikut ini.

Tabel 1

Tugas Pokok Pengawas Penyidik Polri Polres Pinrang

\begin{tabular}{cl}
\hline No. & \multicolumn{1}{c}{ Tugas Pokok Pengawas Penyidik } \\
\hline 1 & $\begin{array}{l}\text { Melakukan koordinasi dan pengawasan proses penyidikan } \\
\text { tindak pidana di lingkungan satuan Reskrim serta menindak } \\
\text { lanjuti pengaduan masyarakat yang terkait dengan dengan } \\
\text { proses penyidikan }\end{array}$ \\
\hline 2 & $\begin{array}{l}\text { Pengawasan pelaksanaan penyelidikan danpenyidikan tindak } \\
\text { pidana yang oleh penyidik/penyidik pembantu pada Sat } \\
\text { Reskrim. }\end{array}$ \\
\hline 3 & $\begin{array}{l}\text { Pelaksanaan supervisi, koreksi dan asistensi kegiatan } \\
\text { penyidikan dan penyelidikan tindak pidana. }\end{array}$ \\
\hline 4 & $\begin{array}{l}\text { Pengkajian efektifitas pelaksanaan penyidikan dan } \\
\text { penyelidikan tindak pidana melalui gelar perkara. }\end{array}$ \\
\hline 5 & $\begin{array}{l}\text { Pemberian saran masukan kepada Kasat Reskrim terkait } \\
\text { dengan hasil pengawasan penyidikan, termasuk menjawab } \\
\text { pengaduan masyarakat. }\end{array}$ \\
\hline 6 & $\begin{array}{l}\text { Pemebrian bantuan penyidikan dan penyelidikan tindak } \\
\text { pidana umum yang dilakukan oleh penyidik pada Sat } \\
\text { Reskrim }\end{array}$ \\
\hline 7 & $\begin{array}{l}\text { Bertanggungjawab atas pelaksanaan tugas dan kewajiban } \\
\text { kepada Kapolres Pinrang dan Kasat Reskrim dan dibantu } \\
\text { oleh para Kanit Riksa. }\end{array}$ \\
\hline
\end{tabular}

Sumber: Polres Pinrang, 2021

Sementara tugas pokok kepala urusan pembinaan operesional (Kaur Bin Ops/KBO) Reskrim Polres Pinrang dapat dilihat pada tabel 2 berikut ini.

Tabel 2

Tugas Pokok KBO Reskrim Polres Pinrang

\begin{tabular}{ccc}
\hline No. & \multicolumn{1}{c}{ Tugas Pokok Kaur Bin Ops/KBO } \\
\hline 1 & $\begin{array}{l}\text { Membantu Kasat Reskrim dalam melaksanakan pembinaan } \\
\text { personil Satuan Reskrim melalui analisis dan gelar perkara } \\
\text { beserta penanganannya. }\end{array}$ \\
\hline 2 & $\begin{array}{l}\text { Mempelajari dan mengkaji efektivitas pelaksanaan tugas } \\
\text { penyelidikan dan penyidikan. }\end{array}$ \\
\hline 3 & $\begin{array}{l}\text { Melaksanakan latihan fungsi, serta menghimpun dan } \\
\text { memelihara berkas perkara yang telah selesai diproses dan } \\
\text { bahan literatur yang terkait. }\end{array}$ \\
\hline 4 & $\begin{array}{l}\text { Mengumpulkan dan mengolah data, serta menyajikan } \\
\text { informasi dan dokumentasi program kegiatan. }\end{array}$ \\
\hline 5 & Mengkordinasikan giat unit-unit oprasional. \\
\hline
\end{tabular}

6 Memberikan pelayanan terhadap keluhan masyarakat dalam penanganan kasus

7 Melaksanakan latkat puan fungsi Reskrim.

8 Melakukan pengawasan terhadap kinerja penyidik

9 Melaksanakan pengawasan penyelidikan dan penyidikan tindak pidana.

10 Melakukan supervisi, koreksi dan asistensi kegiatan peyelidikan dan penyidikan tindak pidana

11 Pemberian bantuan penyelidikan dan penyidikan tindak pidana

12 Dalam melakukan tugas dan kewajiban bertanggungjawab kepada Kasat Reskri.

Sumber: Polres Pinrang, 2021

Dari kedua tabel tersebut di atas, dapat diketahui bahwa tugas pokok sebagai seorang pengawas penyidik ada 7 (tujuh) point, sedangkan tugas pokok kepala urusan pembinaan operesional (Kaur Bin Ops/KBO) ada 12 (dua belas) point. Kalau kedua tugas pokok tersebut dijumlahkan maka ada 19 point. Apabila 19 point dilakukan oleh hanya 1 (satu) orang maka dapat dikatakan berat sehingga tidak dapat dilakukan dengan maksimal yang berdampak pada sulitnya untuk mencapai kinerja yang baik.

Kurangnya sumber daya manusia menyebabkan tidak semua proses penyidikan dapat diawasi. Dengan demikian maka tidak bisa dipastikan apakah proses penyidikan yang dilakukan oleh penyidik telah memenuhi hak-hak tersangka sebagaimana yang diatur di dalam aturan yang berlaku. Bisa saja proses penyidikan yang dilakukan terdapat pelanggaran terhadap hak-hak tersangka yang seharusnya dipenuhi. Tapi karena tidak diawasi maka bisa saja tersangka mendapatkan perlakukan yang tidak seharusnya. Apalagi di wilayah hukum Polres Pinrang ada 10 (sepuluh) Polsek yang juga melakukan proses penyidikan terhadap tersangka di wilayah hukum mereka.

\section{KESIMPULAN DAN SARAN}

Hasil penelitian dan pembahasan dapat disimpulkan bahwa bentuk pelaksanaan kinerja Pengawas Penyidik terhadap pemenuhan hak tersangka di Polres Pinrang telah dilakukan dalam bentuk monitoring, eksaminasi dan supervisi, namun belum berjalan sebagaimana mestinya, karena hanya di kantor Polres Pinrang sendiri yang dapat diawasi dengan baik sementara di Polsek belum berjalan dengan baik; dan faktor yang memengaruhi pelaksanaan kinerja Pengawas Penyidik terhadap pemenuhan hak tersangka di Polres Pinrang adalah aturan hukum aturan hukum yang ada belum mengakomodir cara pelaksanaan pengawasan, hanya memberikan legalitas kepada Pengawas Penyidik, sarana dan prasarana masih sangat kurang seperti tidak adanya ruangan khusus dan kendaraan operasional bagi Pengawas Penyidik, dan sumber daya manusia hanya 1 (satu) orang Pengawas Penyidik, yakni Kepala Urusan Pembinaan Operesional (Kaur Bin Ops/KBO), yang bertugas juga membantu Kasat Reskrim Polres Pinrang.

\section{DAFTAR PUSTAKA}

Andi Hamzah. 2014. Hukum Acara Pidana Edisi Kedua. Sinar Grafika, Jakarta.

Baso Madiong. 2019. Sosiologi Hukum (Suatu Pengantar). SAH Media, Makassar.

I Ketut Adi Purnama. 2018. Transparansi Penyidik Polri dalam Sistem Peradilan Pidana di Indonesia. Jakarta: Refika Aditama. 
I Ketut Adi Purnama, 2018. Hukum Kepolisian: Sejarah dan Peran Polri dalam Penegakan Hukum Serta Perlindungan HAM. Refika Aditama, Jakarta.

Irianto. 1998. Penyiksaan dan HAM dalam Perspektif KUHAP. Pustaka Sinar Harapan, Jakarta.

Irwansyah. 2020. Penelitian Hukum: Pilihan Metode \& Praktik Penulisan Artikel. Mirra Buana Media, Yogyakarta.

Marwan Mas. 2011. Pengantar Ilmu Hukum. Ghalia Indonesia, Jakarta.

Marwan Mas. 2018. Hukum Konstitusi dan Kelembagaan Negara. PT RajaGrafindo Persada, Jakarta.

Moeljatno. 2009. Asas-Asas Hukum Pidana. Rineka Cipta, Jakarta.

Muhammad Erwin. 2016. Filsafat Hukum: Refleksi Kritis terhadap Hukum dan Hukum Indoesia (dalam Dimensi Ide dan Aplikasi) Edisi Revisi. PT RajaGrafindo Persada, Jakarta.

Munir Fuady. 2011. Teori Negara Hukum Modern. Refika Aditama, Bandung.

Nurfaika Ishak. 2019. Implementation and Supervision of Official Discretion in Local Government of Republic of Indonesia. Jurnal Al Daulah: Jurnal Hukum Pidana dan Ketatanegaraan. Vol.8 No.2 Desember 2019.

Pudi Rahardi. 2016. Hukum Kepolisian: Kemandirian Profesionalisme dan Repormasi Polri. Laksbang Grafika, Surabaya.

Ruslan Renggong. 2016. Hukum Acara Pidana: Memahami Perlindungan HAM dalam Proses Penahanan di Indonesia. Prenadamedia Group, Jakarta.

Ruslan Renggong.. 2018. Hukum Pidana Lingkungan. Prenadamedia Group, Jakarta.

Sadjijono. 2008. Seri Hukum Kepolisian: Polri dan Good Governance. Laksbang Mediatama, Surabaya.

Supriadi. 2014. Etika \& Tanggung Jawab Profesi Hukum di Indonesia. Sinar Grafika, Jakarta.

Zainuddin Ali. 2014. Metode Penelitian Hukum. Sinar Grafika, Jakarta.

Zainuddin Ali. 2015. Sosiologi Hukum. Sinar Grafika, Jakarta.

Undang-Undang Dasar Negara Republik Indonesia Tahun 1945.

Undang-Undang Nomor 8 Tahun 1981 tentang Kitab UndangUndang Hukum Acara Pidana (KUHAP).

Undang-Undang Nomor 2 Tahun 2002 Tentang Kepolisian Negara Republik Indonesia.

Peraturan Kapolri Nomor 12 Tahun 2009 tentang Pengawasan dan Pengendalian Penanganan Perkara Pidana di Lingkungan Kepolisian Negara Republik Indonesia.

Peraturan Kapolri Nomor 14 Tahun 2012 tentang Manajemen Penyidikan Tindak Pidana.

Peraturan Kapolri Nomor 6 Tahun 2019 tentang Penyidikan Tindak Pidana.

Peraturan Kepala Badan Reserse Kriminal Kepolisian Negara Republik Indonesia Nomor 4 tahun 2014 tentang Standar operasional Prosedur pengawan penyidik tindak pidana 